\title{
Brevipalpus-associated viruses in the central Amazon Basin
}

\author{
José Carlos V. Rodrigues ${ }^{1}$, Lucille M.K. Antony ${ }^{2}$, Renato B. Salaroli ${ }^{3} \&$ Elliot W. Kitajima ${ }^{3}$
}

${ }^{1}$ University of Puerto Rico, Jardim Botanico Sur, San Juan, PR 00926, USA; ${ }^{2}$ Departamento de Ecologia, Instituto Nacional de Pesquisas da Amazonia, Av. Efigênio Sales 2239, 69060-020, Manaus, AM, Brazil; ${ }^{3}$ Departamento de Entomologia, Fitopatologia \& Zoologia Agricola, ESALQ, Universidade de São Paulo, Cx. Postal 9, 13418-900 Piracicaba, SP, Brazil

Corresponding author: José Carlos V. Rodrigues, e-mail: jose_carlos@mac.com

\begin{abstract}
A survey of Brevipalpus-transmitted plant viruses (BTrV) was carried out in the cities of Manaus and Presidente Figueiredo, and in the oil exploratory base of Urucu, Amazonas State, Central Amazon Basin, Brazil. The main characteristics considered during the survey were the occurrence of localized symptoms (chlorotic or brown spots, ringspots, green spots in senescent leaves) similar to those previously described for BTrV and infestation by Brevipalpus mites. For the evaluation of the infection by putative BTrV, small fragments of the leaf lesions were fixed in loco and later processed for ultrastructural electron microscopy at Piracicaba, SP. Thirteen plant hosts of presumed $\mathrm{BTrV}$ were found. Three of them probably represent previously described BTrV infecting Hibiscus rosa sinensis, H. syriacus and Clerodendrum x speciosum. For the first time we report cases of infection by putative BTrV of nuclear type in chlorotic spot in Piper callosum (Piperaceae), chlorotic ringspot in Monstera deliciosa (Araceae), chlorotic spot in Ruellia chartacea (Acanthaceae), chlorotic spot in Bidens sp. (Asteraceae), green spot in Allamanda chatartica (Apocynaceae), chlorotic spot in Gardenia sp. (Rubiaceae), chlorotic ringspot and green spot in Mussaenda erythrophylla. (Rubiaceae) and of cytoplasmic type in Clerodendrum speciosissimum (Lamiaceaae) and ringspots in Arundina graminifolia (Orchidaceae). All these plants were infested by Brevipalpu. phoenicis.
\end{abstract}

Keywords: cytopathology, Acari, Tenuipalpidae, Brevipalpus phoenicis, flat mite, invasive species.

\section{RESUMO}

Viroses associadas a Brevipalpus na Amazônia Central

Foi feito um levantamento no estado do Amazonas, na região da capital Manaus, na base de exploração de petróleo de Urucu (700 km a sudoeste de Manaus) e em Presidente Figueiredo (100 km ao norte de Manaus) à procura de vírus transmitidos por ácaros Brevipalpus (VTrB) em diferentes espécies de plantas. Foram coletadas 33 espécies de plantas caracterizadas por lesões localizadas em folhas (manchas cloróticas, manchas anelares, manchas verdes em folhas senescentes) e pela presença de ácaros Brevipalpus (os quais foram coletados para identificação e avaliação de sua diversidade) em plantas cultivadas, ornamentais e silvestres. Fragmentos das lesões foram fixados no local e processados para microscopia eletrônica ultraestrutural e examinados em Piracicaba, SP. Foram constatados treze casos positivos de detecção de efeitos citopáticos do tipo citoplasmático ou nuclear de VTrB nas plantas coletadas em Manaus. Três deles parecem representar casos anteriormente descritos de VTrB em Hibiscus rosa sinensis, H. syriacus e Clerodendrum x speciosum. Presumíveis VTrB do tipo nuclear foram constatados em mancha clorótica em Piper callosum (Piperaceae), mancha clorótica anelar em Monstera deliciosa (Araceae), mancha clorótica em Ruellia chartacea (Acanthaceae), manchas cloróticas em Bidens sp. (Asteraceae), mancha verde em Allamanda chatartica (Apocynaceae), mancha clorótica em Gardenia sp. (Rubiaceae), mancha verde em Mussaenda erythrophylla (Rubiacea) e do tipo citoplasmático em mancha clorótica em Clerodendrum speciosissimum (Lamiaceae) e mancha anular em Arundina graminifolia (Orchidaceae). Todas estas plantas achavam-se naturalmente infestadas por Brevipalpus phoenicis.

Palavras-chaves: citopatologia, Acari, Tenuipalpidae, Brevipalpus phoenicis, ácaros planos, espécies invasivas.

\section{INTRODUCTION}

Brevipalpus-transmitted viruses (BTrV) or putative $\mathrm{BTrV}$ have been described in more than 40 plant species (Kitajima et al., 2003; 2006, Nogueira et al., 2003). A common feature of diseases associated with these viruses is that they usually induce consistently localized symptoms in the leaves, stems, fruit and sometimes in the flower of the host plants. BTrV or putative BTrV have been grouped in two types based upon comparative cytopathology of the lesions (Kitajima et al., 2003). The first type is characterized by the accumulations of short, bacilliform particles in the cisternae of the endoplasmatic reticulum of the infected cells and the presence of large electron-dense, vacuolated inclusions (viroplasms) in the cytoplasm. This type has been called cytoplasmatic type, with the Citrus leprosis virus cytoplasmatic type (CiLV-C) being the prototype virus in this group, whose genome has been completely sequenced (Pascon et al., 2006). Because the genome organization of $\mathrm{CiLV}-\mathrm{C}$ is different from other known viruses, the genus, 
Cilevirus, has been proposed (Locali-Fabris et al., 2006). The second BTrV group, called nuclear type, is characterized by the occurrence of short, rod-like particles in the nucleus and cytoplasm, and an electron lucent viroplasm in the nucleus of the infected host cell. Orchid fleck virus (OFV) may be considered the type species of the nuclear type of BTrV. Its genome was sequenced and presents similarities to that of rhabdoviruses. Because of the bipartite genome, a new genus, Dichorhabdovirus, was proposed within the family Rhabdoviridae to accommodate OFV (Kondo et al., 2006). In addition to citrus, other plants such as Clerodendrum spp., orchid species and Hibiscus spp., Salvia leucantha Cav. and Spathiphyllum wallisi Regel have been reported as hosts for both types of BTrV (Kitajima et al., 2006).

CiLV-C is one of the most significant economic pest problems in the Brazilian citrus industry and the most important of the Brevipalpus-transmitted disease agents. Control of citrus leprosis is expensive, being based on chemical control of the mite vector, whose populations are monitored through bi-weekly inspections and reduced with frequent acaricide sprays. Other practices, like removal of infected branches and the removal of alternative virus and vector hosts, have been added to the traditional chemical control (Rodrigues, 2002; Rodrigues et al., 2003). The fact that non-citrus plants can also naturally host CiLV-C (Rodrigues et al., 2005; Nunes et al., 2006; Groot et al., 2006) could make the control strategies more complex. It also raises the importance of properly identifying all the other potential BTrV hosts as well as the places where they occur. Beyond the concerns over these viruses in citrus, the growing ornamental industry based on tropical and subtropical plants could be negatively affected by some of the BTrV.

This paper reports thirteen plant hosts collected in the central Amazon Basin that had infestations of Brevipalpus mites, showed localized symptoms, and harbored virus-like particles typical of BTrV in their leaf lesions.

\section{MATERIALS AND METHODS}

Plants were inspected between October 2004 and December 2005 in the region around Manaus (S 03 $04^{\prime}$ / W 59 57'), Urucu (S 04 53' / W 65¹8', $700 \mathrm{~km}$ Southwest of Manaus) and Presidente Figueiredo (S $02^{\circ} 03$ / W 60 $03^{\prime}$ '), Amazonas State, Brazil. The surveys were conducted in natural forest areas, parks, yards, and plant nurseries. Thirtythree plants (Table 1) showing symptoms similar to those described for BTrV's (Kitajima et al., 2003) were sampled for electron microscopy analysis. Small sections of the lesions were fixed immediately after collection in plastic tubes with a modified Karnovsky solution (2.5\% glutaraldehyde and $2 \%$ paraformaldehyde in $0.05 \mathrm{M}$ cacodylate buffer, $\mathrm{pH} 7.2$ ), and sent by mail to Escola Superior de Agricultura Luiz de Queiroz, Universidade de São Paulo, at Piracicaba, SP, for further processing, dehydration and embedding in low viscosity Spurr resin. Embedded tissues were cut with a
Leica UC6 microtome equipped with a diamond knife and the sections stained with uranyl acetate and Reynold's lead citrate (Kitajima \& Nome, 1999). Sections were examined in a Zeiss EM 900 transmission electron microscope.

In the field, symptomatic plants were inspected for the presence of Brevipalpus mites using a 10-20 X-magnification hand lens, and plant twigs and leaves were washed in an ethanol and water (80:20) solution. The solution was taken to the laboratory and inspected for false spider mites. When present, they were slide-mounted in Hoyer's medium and identified by light microscopy (Jeppson et al., 1975). Mite voucher specimens were deposited at "Coleção de Ácaros de Referência para a Segurança Biológica”, Embrapa Recursos Genéticos e Biotecnologia, Brasília, DF.

\section{RESULTS AND DISCUSSION}

Out of thirty-three plant species exhibiting local lesion symptoms on the leaves and analyzed for cytopathology by transmission electron microscopy, thirteen (Figures 1 and 2) showed BTrV-like particles and characteristic inclusions in the parenchymal cells from the leaf lesions (Figures 3 and 4). All of these plant species were infested by Brevipalpus mites, as were most of the plants sampled during this survey (Table 1). These mites were identified as B. phoenicis Geijskes based on Baker (1949) and Baker and Tuttle (1987) keys.

Hibiscus spp. were the plants with the highest occurrence and abundance of green spot symptoms on their leaves throughout the Manaus region. This is widely used as an ornamental plant in gardens and public parks, and because of its vegetative multiplication and evergreen habits, it could be a very effective vehicle for spread of both viruses and vectors to new areas. The green spot symptoms (Figure 2B) were similar to those caused by the previously reported Hibiscus green spot virus (HGSV), a cytoplasmic type of BTrV (Kitajima et al., 1999). Hibiscus (H. rosa sinensis L., H. schizopetalus Hook.f. and H. syriacus L.) is one of the BTrV hosts with the widest geographical distribution. Affected plants were found in several parts of Brazil, in Panama City (Panama), and Havana (Cuba) (Kitajima et al., 2004), and more recently in Bolivia (Kitajima, E.W., unpublished data) and Argentina (Dal Bo et al., 2007). A typical cytoplasmic type of cell alteration was found in the tissues of these green spots (Figure 3 D). Chlorotic spots on $H$. rosa sinensis leaves (image not shown) and brown spots on $H$. syriacus leaves (Figure $1 \mathrm{E}$ ) exhibited a cytopathic effect characteristic of the nuclear type of BTrV (Figures $3 \mathrm{C}$ and $4 \mathrm{G}$ ). These cases may represent infection by the previously described Hibiscus chlorotic spot virus (HibCSV). Cases of the same host plant being susceptible to both types of BTrV or putative BTrV are not uncommon. Citrus spp., Solanum violaefolium Schott., Clerodendrum spp., Salvia leucantha, Pelargnoium $x$ hortorum Hort. and some species of orchids are examples, and in a few instances, co-infection of a single cell by the 
J.C.V. Rodrigues et al.

TABLE 1 - List of plants inspected for Brevipalpus and possible infection by Brevipalpus-transmitted viruses in Amazon region

\begin{tabular}{|c|c|c|c|c|}
\hline Local & Family & Species & $\begin{array}{l}\text { Brevipalpus and } \\
\text { symptoms }^{1}\end{array}$ & $\begin{array}{l}{ }^{2} \text { Cytopathic } \\
\text { effects }\end{array}$ \\
\hline \multirow[t]{29}{*}{ Manaus } & Acanthaceae & Ruellia chartacea (T. Anderson) Wash. & +/ Green spots & $+/ \mathrm{N}$ \\
\hline & & Hemigraphis sp. & + / Dark spots & - \\
\hline & Anonacea & Rollinia orthopetala A.DC. & $+/$ Green spots & - \\
\hline & Apocynaceae & Allamanda cathartica $\mathrm{L}$. & +/ Green spots & $+/ \mathrm{N}$ \\
\hline & Arecaceae & Rhapis excelsa (Thunb.) Henry ex Rehder & $+/$ Chlorotic symptoms & - \\
\hline & Araceae & Monstera deliciosa Liebm. & $+/$ Chlorotic ringspots & $+/ \mathrm{N}$ \\
\hline & & Aglaonema costatum N.E.Br. & $+/$ Chlorotic spots & - \\
\hline & & Aglaonema commutatum Schott & $+/$ Chlorotic spots & - \\
\hline & & Syngonium angustatum Schott & $+/$ Chlorotic spots & - \\
\hline & & & Symptoms - fungi & \\
\hline & Asteraceae & Bidens sp. & $\begin{array}{l}+/ \text { Vein clearing and } \\
\text { ringspots }\end{array}$ & $+/ \mathrm{N}$ \\
\hline & Liliaceae & Dracaena marginata Hort. & $+/$ Chlorotic spots & - \\
\hline & Saxifragaceae & Hydrangea macrophylla (Thunb.) Ser. & $+/$ Brown spots & - \\
\hline & Leguminosae & Mimosa caesalpiniifolia Benth. & $\begin{array}{l}\text { +/ Mite feeding } \\
\text { damage }\end{array}$ & - \\
\hline & Malvaceae & Hibiscus rosa-sinensis $\mathrm{L}$. & + / Green spots & $+/ \mathrm{C}$ \\
\hline & & & +/ Chlorotic spots & $+/ \mathrm{N}$ \\
\hline & & Hibiscus syriacus L. & $+/$ Brown spots & $+/ \mathrm{N}$ \\
\hline & Rubiaceae & Mussaenda erythrophylla Schumach. \& Thonn. & + / Green spots & $+/ \mathrm{N}$ \\
\hline & Myrtaceae & Eugenia uniflora L. & $+/$ Chlorotic spots & - \\
\hline & Orchidaceae & Arundina graminifolia (D. Don) Hochr. & $+/$ Dark spots & $+/ \mathrm{C}$ \\
\hline & Piperaceae & Piper callosum Ruiz et Pav. & $+/$ Chlorotic spots & $+/ \mathrm{N}$ \\
\hline & Polypodiaceae & Platycerium bifurcatum (Cav.) C.Chr & $\begin{array}{l}\text { Tenuipalpus / chlorotic } \\
\text { feeding damage }\end{array}$ & - \\
\hline & Polypodiaceae & Polypodium sp. & $\begin{array}{l}+ \text { and Tenuipalpus / } \\
\text { feeding damage }\end{array}$ & - \\
\hline & Rubiaceae & Ixora sp. & $\begin{array}{l}+/ \text { Chlorotic ringspot } \\
\text { and oak leaf pattern }\end{array}$ & - \\
\hline & Solanaceae & $\begin{array}{l}\text { Brugmansia suaveolens (Willd.) Bercht. \& J. } \\
\text { Presl. }\end{array}$ & - / Chlorotic spots & - \\
\hline & Lamiaceae & Clerodendrum x speciosum Tiejsm. \& Binn & $+/$ Chlorotic spots & $+/ \mathrm{N}$ \\
\hline & & Clerodendrum speciosissimum Paxt. & $+/$ Green spots on & - \\
\hline & & & senescent leaves & $+/ \mathrm{C}$ \\
\hline & Zingiberaceae & Alpinia sp. & $+/$ Chlorotic spots & - \\
\hline \multirow{2}{*}{$\begin{array}{l}\text { Presidente } \\
\text { Figueiredo }\end{array}$} & Malvaceae & Hibiscus rosa-sinensis L. & $+/$ Chorotic spots & - \\
\hline & Rutaceae & Citrus sinensis Osbeck & $+/$ Yellow spots & - \\
\hline \multirow[t]{5}{*}{ Urucu } & Anacardiaceae & Anacardium occidentale L. & - / Chlorotic spots & - \\
\hline & Malvaceae & Hibiscus rosa-sinensis L. & $+/$ Chlorotic spots & - \\
\hline & Orchidaceae & Maxillaria sp. & $+/$ Chlorotic spots & - \\
\hline & & Stanhopea candida Barb. Rodr. & - / Chlorotic spots & - \\
\hline & Rubiaceae & Gardenia sp. & $+/$ Chlorotic spots & $+/ \mathrm{N}$ \\
\hline
\end{tabular}

${ }^{1}+$ Presence of Brevipalpus mites ; - absence.
${ }^{2}+$ Presence and - absence of cytopathic effects in the tissues of the lesion. $\mathrm{C}=$ Cytopathic effect of the cytoplasmatic type of Brevipalpus transmitted viruses; $\mathrm{N}=$ idem, of nuclear type. 

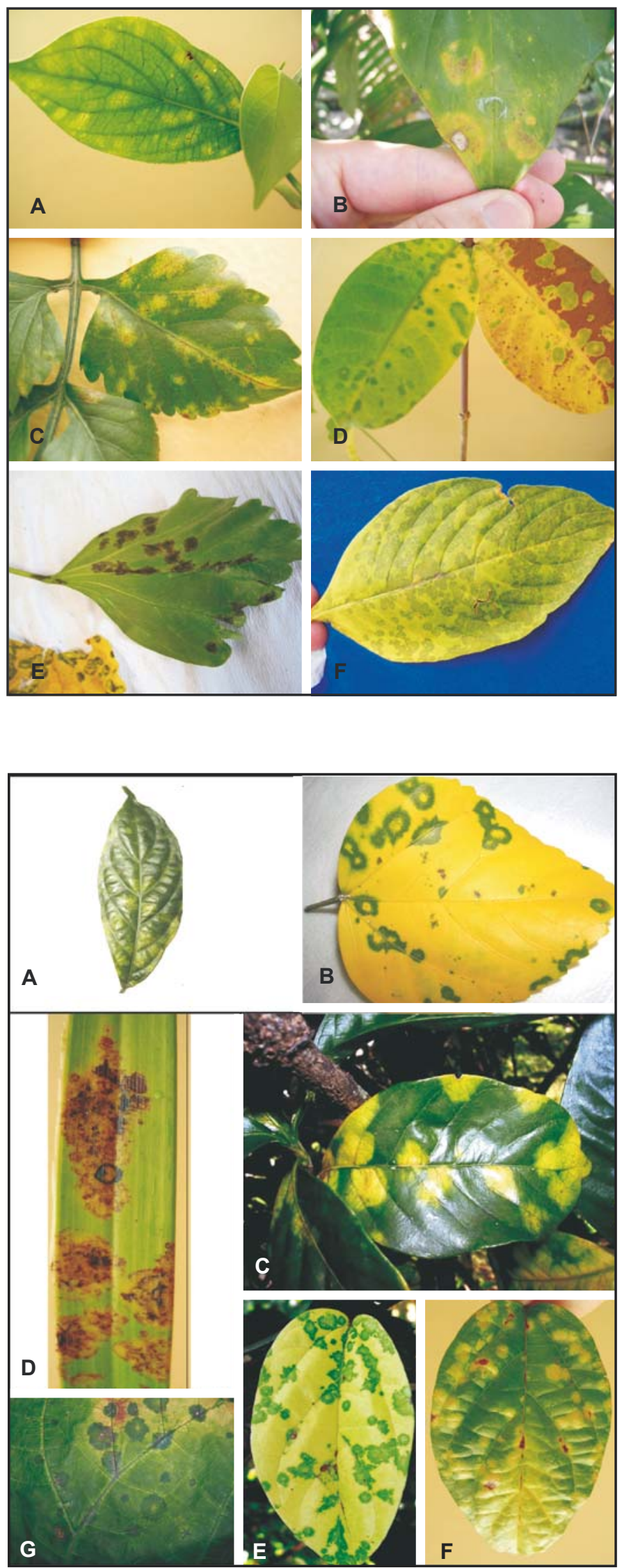

FIGS. 1 and 2 - Leaf lesions in different plant specieAs associated with the infection of presumed viruses transmitted by Brevipalpus (Tenuipalpidae) mites found in the Amazon basin.

FIG. 1 - A. Chlorotic lesions - Piper callosum; B. Chlorotic ringspot - Monstera deliciosa; C. Chlorotic spots/Bidens sp.; D. Green spots on senescent leaves - Allamanda cathartica; E. Brown spots - Hibiscus syriacus; F. Green spots on senescent leaves Mussaenda erythrophylla.
FIG. 2 - A. Chlorotic spots - Ruellia chartacea; B. Green spots - Hibiscus rosa sinensis; C. Chlorotic spots - Gardenia sp. D. Brown ringspots - Arundina graminifolia; E. Green spots on senescent leaves and chloroctis spots; F. Clerodendrum x speciosum; G. Green spots - C. speciosissimum. 

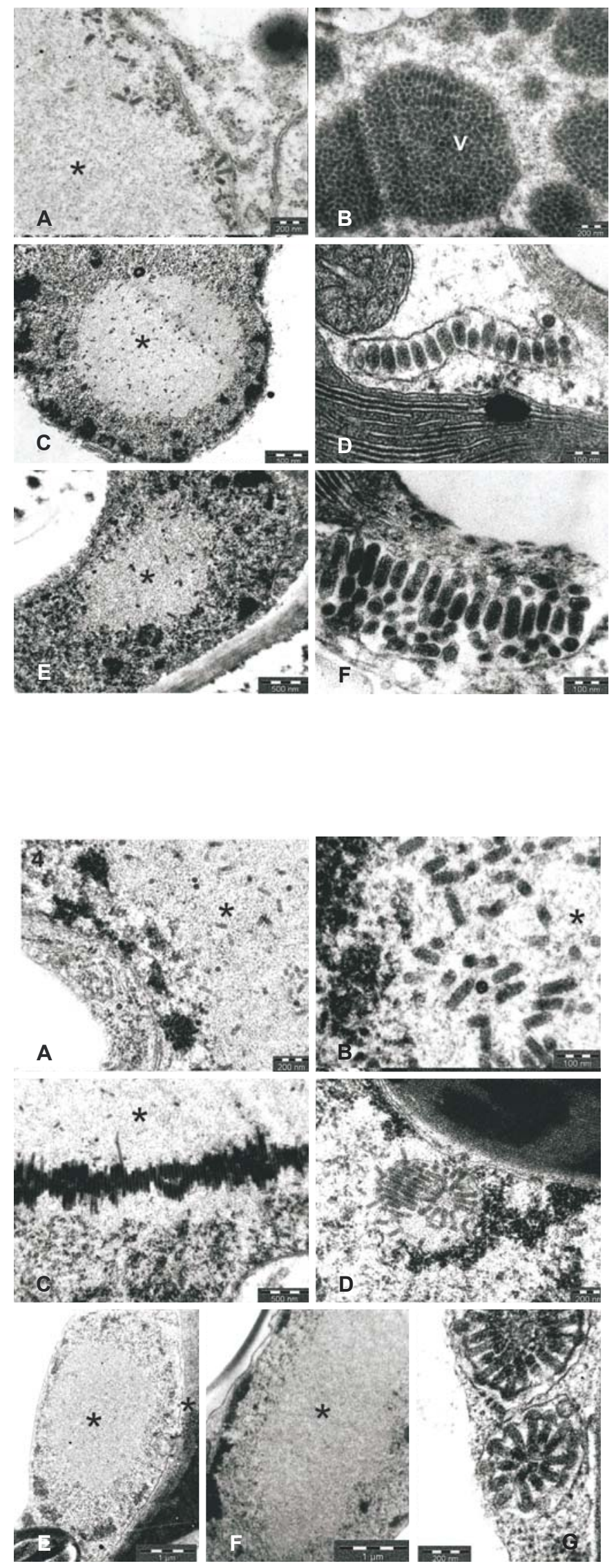

FIGS 3 and 4 - Transmission electron micrographs of thin sections of the leaf lesions from different plant species, showing either the nuclear $(\mathrm{N})$ or cytoplasmic (C) type of cytopathology, caused by viruses transmitted by Brevipalpus mites (BrTV) observed in specimens collected in the Amazon basin.

FIG. 3 - A. Nuclear type of BrTV cytopathology (electron lucent viroplasm [*] in the nucleus and short rod-like particles in the nucleus and cytoplasm) in the chlorotic spots on Clerodendrum x speciosum; B. A large aggregate of short, bacilliform particles (v) in the cisternae of the endoplasmic reticulum, characteristic of the cytoplasmic type of cytopathology in the parenchymal cell of the green spots on leaves of C. speciosissimum; C. Nuclear type of cytopathology in a parenchymal cell of chlorotic spots on the leaves of Hibiscus rosa sinensis. A viroplasm $(*)$ is clearly seen in the nucleus, in which rod-like particles are interspersed; D. Section through green spots on senescent leaves of $H$. rosa sinensis. A row of short, bacilliform particles can be seen within cisternae of the endoplasmic reticulum; E. Electron lucent viroplasm (*) in the nucleus of a parenchymal cell from a chlorotic lesion on the leaf of Piper callosum; F. Group of short bacilliform particles contained in the endoplasmic reticulum in a parenchymal cell from the brown spot on the leaf of Arundina gaminifolia.
FIG. 4 - A. Part of the nucleus of leaf parenchymal cells from the chlorotic lesions in Bidens sp. Viroplasm $\left(^{*}\right)$ and short rod-like particles can be seen; B. Detail of a group of rodlike particles in the nucleus of parenchymal cells in the green spots on the leaves of Allamanda cathartica; C. A lamellar aggregate of rod-like particles immersed in the viroplasm of a parenchymal cell nucleus in the chlorotic ringspot of Monstera deliciosa leaf; D. Group of rod-like particles producing the so-called "spokewheel" pattern in the cytoplasm of a chlorotic lesion on Ruellia chartacea leaf; $\mathbf{E}$ and F. Nuclear viroplasm $\left.{ }^{*}\right)$ in parenchymal cells from chlorotic lesions on the leaves of Gardenia sp.; E. and Mussaenda erythrophylla; F. respectively; G. Detail of spokewheel configurations of viral particles in a parenchymal cell of a leaf lesion of Hibiscus syriacus. 
two types has been observed (Kitajima et al., 2003; 2006).

Bleeding heart (Clerodendrum $x$ speciosum Tiejsm. \& Binn.) plants with chlorotic spots and green spots in senescent leaves (Figures $2 \mathrm{E}$ and $\mathrm{F}$ ) were found in a residential garden in Manaus, associated with B. phoenicis infestation. Electron microscopic examination of the lesions revealed that chlorotic spots (Figure $2 \mathrm{~F}$ ) showed cytopathic effect of the nuclear type of BTrV (Figure $3 \mathrm{~A}$ ), while in the tissues of the green spot lesions, cell alterations were of the cytoplasmic type of BTrV. As in the case of Hibiscus spp., bleeding heart is susceptible to both types of BTrV (Kitajima et al., 2003). The putative nuclear type of BTrV found in bleeding heart is probably the previously described Clerodendrum chlorotic spot virus (ClCSV) (Kitajima \& Moraes, 2000; Kitajima et al., 2007), which was recently purified and had its genome partially sequenced (Boari et al., 2006; Kubo, K.S., unpublished data). Another species of Clerodendrum found in Manaus, C. speciosissimum Paxt., with green spot symptoms (Figure $2 \mathrm{G}$ ), showed a cytoplasmic type cytopathology in the cells of the lesion (Figure $3 \mathrm{~B}$ ). This is a new species of the genus Clerodendrum (Lamiaceae) found to be infected with a putative BTrV, besides C. x speciosum, C. thomsonae Bauf. and $C$. splendens Don. (Kitajima et al., 2003; 2006).

This survey revealed other previously unreported host plant species for putative BTrV (Table 1) such as Ruellia chartacea (T. Anderson) Wash. (Acanthaceae) (Figure 2 A), Allamanda cathartica L. (Apocynaceae) (Figure 1 D), Monstera deliciosa Liebm. (Araceae) (Figure 1 B), Bidens sp. (Asteraceae) (Figure 1 C), Mussaenda erythrophylla Schumach. \& Thonn. (Figure 1 F) and Gardenia sp. (Figure 2 C) (Rubiaceae) and Piper callosum Ruiz et Pav. (Piperaceae) (Figure 1A). They exhibited symptoms and cytopathological features consistent with those of BTrV's (Figures $4 \mathrm{~A} /$ Bidens sp.; $4 \mathrm{~B} /$ Allamanda cathartica; 4 C/Monstera deliciosa; 4 D/Ruellia chartacea; 4 E/Gardenia sp.; 4 F/Mussaenda erythrophylla).

Gardenia chlorotic spot (Figure 2 C) was associated with the presence of a putative nuclear type BTrV (Figure 4 E). The symptomatic plants were located in Urucu, which is an isolated oil and gas exploration facility located in the forest about $700 \mathrm{~km}$ southwest of Manaus. The infected plants were observed in a garden around the dormitories within this oil exploration complex. No other BTrV's were found in native or ornamental plants in the vicinity, which suggests that the virus and vector were introduced with the Gardenia sp. plants brought in for the garden. This reinforces the concern that ornamental plants could act as pathways for the introduction of these viruses into new areas. Most of the virus hosts found in this study were plants that are not native to the Amazon.

Ixora sp. (image not shown), Piper callosum (Figure 1A) and Ruellia chartacea (Figure 2A) with chlorotic spots, Monstera deliciosa (Figure 1B) with ringspots, and Mussaenda erythrophylla (Figure $1 \mathrm{~F}$ ) and Allamanda chartacea (Figure 1D) with green spots, (Figures 3 C, 4 D,
$4 \mathrm{C}, 4 \mathrm{~F}$ and $4 \mathrm{~B}$, respectively) showed cell changes of the nuclear type of BTrV. However, there is no information about whether or not these putative nuclear types of $\mathrm{BTrV}$ found in these plants are distinct from other viruses previously reported. There is one previous description in the Amazon basin (Tome Açú, State of Pará) of a putative nuclear type of BTrV in black pepper (Piper nigrum L.) (Yamashita et al., 2004).

Bidens sp., a common Asteraceae weed, was found with chlorotic spots on the leaves (Figure $1 \mathrm{C}$ ), associated with infestation by B. phoenicis, and cytopathology typical of the nuclear type of BTrV (Figure $4 \mathrm{~A}$ ) in the tissues of the lesions. In Gainesville, Florida and in San Juan, Puerto Rico, the senior author observed high infestations of $B$. phoenicis mites on Bidens pilosa L. plants, although neither symptoms nor virus particles were detected. Also in Florida, Knorr (1968) reported that a year after Brevipalpus mites were transferred from non-symptomatic Bidens plants to sweet orange seedlings, leprosis-like symptoms appeared on the sweet orange. Because assays were conducted with citrusto-citrus transmission at the same time, cross-contamination could have occurred. However, these results, along with our observations in the field and the growing list of Brevipalpustransmitted virus hosts, strongly suggest that the BTrV can move between different plant species, genera, or families (Rodrigues et al., 2005).

The only example, in this survey, of the putative cytoplasmic type BTrV in the Amazon basin, besides HGSV and the green spots on C. $x$ speciosum leaves, was found in leaf tissues of Arundina graminifolia (D. Don) Hochr., an orchid found growing in Manaus. RT-PCR conducted using primers designed for Orchid fleck virus (OFV-nuclear type) (Blanchfield et al., 2001), did not generate amplification products from A. graminifolia samples (Karen S. Kubo, unpublished data). This putative cytoplasmic type BTrV found in Arundina may be similar to that previously found in São Paulo State (Freitas-Astua et al., 1999). Like most of the putative BTrV-positive plants reported in this work, the terrestrial bamboo orchid, A. graminifolia, is an exotic species in the Amazon region, introduced from Southeast Asia, which has been heavily cultivated and naturalized in some tropical areas (Smith, 1991). This plant could represent an additional source for the introduction of plant pests and viruses, as well as being a reservoir for them.

Crops such as coffee (Coffea arabica L.), sweet orange (Citrus sinensis (L.) Osbeck) and passion fruit (Passiflora edulis Sims. f. flavicarpa Deg.) are economically important host plants for BTrV, and these plants were inspected for possible infection by these viruses during the current study. Despite the occurrence of infestation by Brevipalpus mites, no symptoms attributable to BTrV were observed. There are recent reports of the detection of CiLV-C in sweet orange plantations in Itacotiara and Manaus, AM (Freitas-Astua et al., 2006) and Capitão Poço, state of Pará (Boari et al., 2007).

During the development of this work, a few BTrV 
genomes were partially or completely sequenced: OFV (Kondo et al., 2006), Coffee ringspot virus (CoRSV) (Locali etal., 2005), ClCSV (Karen S. Kubo, unpublished data), citrus leprosis of the cytoplasmic type (CiLV-C) (Pascon et al., 2006; Locali-Fabris et al., 2006) and Solanum violaefolium ringspot virus (SvRSV) (Ferreira et al., 2004). Antibodies are also now available for OFV, CoRSV (Boari et al., 2004) and ClCSV (Boari et al., 2007). This information will be useful in the further characterization of the putative BTrV reported here using molecular and immunological tools to confirm their relationship with better-characterized BTrV.

Haramoto (1969) suggested that the genus Brevipalpus originated in the tropics although it was first described in Northern Europe. This assumption could be extended to the viruses vectored by Brevipalpus, based on the growing number of plants reported to be susceptible to BTrV in tropical regions. (Childers et al., 2003). If these viruses did not originate in the tropics then these regions are probably new centers of diversification, perhaps because of the favorable conditions for spread and perseverance. It should be mentioned that so far, BTrV's and putative BTrV's have been found only in the American continent (Kitajima et al., 2003; 2006), except OFV, which has a worldwide distribution due to the intense exchange of orchids by collectors and global trade. The same fate may occur with other ornamentals, as many of them seem to be susceptible to BTrV's and putative BTrV's. An introduction of the Brevipalpus mite vector and the virus may result in their spread to other ornamentals and cultivated plants, further stressing the potential importance of this virus group.

\section{ACKNOWLEDGEMENTS}

Thanks are due to Conselho Nacional de Desenvolvimento Científico e Tecnológico - CNPq for providing two visiting fellowships (October, 2004 and January, 2007); CT-Petro Amazônia Network; Finep for partial support for the project "Artificial regeneration technology applied to forest gaps resulting from oil and gas exploration"; Petrobrás for financial and logistic support; Amazon Biotechnology Center (CBA)/Biochemistry and Molecular Biology Laboratory and Fapeam, Manaus for a Fix-1A fellowship (2005) to the senior author. This work received financial support from Fundação de Amparo do Estado de São Paulo FAPESP (Proc. 2000/11805-0). Thanks are due to Priscilla Antony (INPA) for help with identification of some symptomatic plant species, to Dra. Denise Navia, Embrapa/Cenargen, for receiving the voucher specimens, and to S. C. Garrett-Rodrigues for reviewing a draft version of the manuscript.

\section{REFERENCES}

BakerEW (1949) The genus Brevipalpus (Acarina: Pseudoleptidae). American Midland Naturalist 42:350-402.
Baker EW, Turtle DM (1987) The false spider mites of Mexico (Tenuipalpidae: Acari). US Department Agriculture, Technical Bulletin 1706.

Blanchfield AL, Mackenzie AM, Gibbs A, Kondo H, Tamada T, Wilson CR (2001) Identification of Orchid fleck virus by reverse transcriptase-polymerase chain reaction and analysis of isolate relationships. Journal of Phytopathology 149:713-718.

Boari AJ, Freitas-Astúa J, Ferreira PTO, Neder DG, Nogueira NL, Rossi ML, Kitajima EW (2004) Purification and serology of the coffee ringspot virus. Summa Phytopathologica 30:453-458.

Boari AJ, Kubo KS, Alcântara BK, Kitajima EW (2006) Purificação do vírus da mancha clorótica do Clerodendron. Summa Phytopathologica 32 (Supl):11.

Boari AJ, Penner G, Figueiredo SBQ, Freitas-Astúa J, Kitajima EW (2007) Confirmação da presença da leprose dos citros, tipo citoplasmático, no Estado do Pará. Fitopatologia Brasileira 32 (Supl):207.

Childers CC, Rodrigues JCV, Welbourn WC (2003) Host plants of Brevipalpus californicus, B. obovatus, and B. phoenicis (Acari: Tenuipalpidae) and their potential involvement in the spread of one or more viral diseases vectored by these mites. Experimental and Applied Acarology 30:9-105.

Dal Bo E, Pena E, Fernandéz R, Kubo K, Freitas-Astúa J, Bedendo IP, Kitajima EW (2007) Busca preliminar de viroses de ornamentales en la región de La Plata, Argentina. Fitopatologia Brasileira 32 (Supl):135.

Ferreira PTO, Locali-Fabris EC, Freitas-Astúa J, Antonioli-Luizon R, Gomes RT, Machado MA, Kitajima EW (2007) Caracterização de um vírus baciliforme isolado de Solanum violaefolium transmitido pelos ácaros Brevipalpus phoenicis e Brevipalpus obovatus (Acari: Tenuipalpidae). Summa Phytopathologica 33:264-269.

Freitas-Astúa J, Rezende JAM, Kitajima EW (1999) Incidence of orchid viruses in the State of São Paulo, Brazil. Fitopatologia Brasileira 24:125-130.

Freitas-Astúa J, Novelli VM, Rodrigues V, Caetano AA, AntonioniLuisoni R, Locali-Fabris EC, Bastianel M, Kitajima EW, Lopes SA, Machado MA (2006) Ocorrência da leprose dos citros no Estado de Amazonas. Fitopatologia Brasileira 31 (Supl):265.

Groot TVM, Freitas-Astúa J, Kitajima EW (2006) Brevipalpus phoenicis transmits citrus leprosis virus, cytoplasmic type (CiLVC) to common bean (Phaseolus vulgaris) under experimental conditions. Virus Review \& Research 11 (Suppl):67-68.

Haramoto FH (1969) Biology and control of Brevipalpus phoenicis (Geijskes) (Acarina: Tenuipalpidae). Technical Bulletin, Hawaii Agricultural Experiment Station, No. 68.

Jeppson LR, Keifer HH, Baker EW (1975) Mites injurious to economic plants. Berkeley CA. University of California Press.

Kitajima EW, Moraes GJ (2000) Manchas cloróticas em Clerodendron speciosum e mancha anular em Solanum violaefolium associadas a efeitos citopáticos similares aos dos vírus transmitidos pelo ácaro Brevipalpus. Summa Phytopathologica 26:133-134.

Kitajima EW, Nome C (1999) Microscopia electronica em virologia vegetal. In: Docampo DM, Lenardon SL (Eds.) Métodos para detectar patógenos sistêmicos. Córdoba, Instituto de Fitopatologia y Fisiologia Vegetal/INTA-JICA. pp. 59-87.

Kitajima EW, Novaes QS, Rezende JAM, Moraes GJ (1999) Short 
rhabdo-virus-like particles and a caulimovirus in Hibiscus rosasinensis with green spot. Proceedings 51st Annual Meeting of the Scandinavian Society for Electron Microscopy (Sandem 99): p. 63-64.

Kitajima EW, Chagas CM, Rodrigues JCV (2003) Brevipalpustransmitted plant virus and virus-like diseases: cytopathology and reports of some recent cases. Experimental and Applied Acarology 30:135-160.

Kitajima EW, Rodrigues JCV, Salaroli RB, Gonzáles G (2004) Distribution of the hibiscus green spot virus in the Americas. Virus Review \& Research 9 (Suppl):248.

Kitajima EW, Moraes G.J, Rodrigues JCV, Freitas-Astúa J (2006) Plantas infectadas naturalmente por vírus transmitidos pelo ácaro Brevipalpus (Acari: Tenuipalpidae). Resumos, $1^{\circ}$ Simpósio Brasileiro de Acarologia, Viçosa MG. p. 251.

Kitajima EW, Kubo KS, Ferreira PTO, Alcântara BK, Boari AJ, Gomes RT, Freitas-Astúa J, Rezende JAM, Moraes GJ, Salaroli RB (2007) Clerodendrum chlorotic spot, a disease caused by a nuclear type of Brevipalpus (Acari: Tenuipalpidae)-transmitted virus. Scientia Agrícola 65:36-49.

Kondo H, Maeda T, Shirako Y, Tamada T (2006) Orchid fleck virus is a rhabdovirus with an unusual bipartite genome. Journal of General Virology 87:2413-2421.

Knorr LC (1968) Studies on the etiology of leprosis in citrus. Proceedings, $4^{\text {th }}$. Conference of International Organization of Citrus Virologists. pp. 332-340.

Locali EC, Freitas-Astúa J, Antonioli-Luizon R, Boari AJ, Machado MA (2005) Diagnose da mancha anular do cafeeiro através do RTPCR. Fitopatologia Brasileira 30 (Supl.): 185.

Locali-Fabris E, Freitas-Astúa J, Souza AA, Takita MA, AstuaMonge G, Antonioli-Luizoni R, Rodrigues V, Targon MLPN, Machado MA (2006) Complete nucleotide sequence, genomic organization and phylogenetic analysis of Citrus leprosis virus cytoplasmic type. Journal of General Virology 87:2721-2729.

Nogueira NL, Rodrigues JCV, Rossi ML (2003) Association of rhabdovirus-like particles and Brevipalpus mites with three ornamental plants exhibiting symptoms of local lesions. Summa Phytopathologica 29:278-282.

Nunes MA, Kitajima EW, Freitas-Astúa J, Hilf ME, Gottwald TR, Oliveira CAL (2006) Infecção de hibisco e malvavisco pelo vírus da leprose dos citros através de Brevipalpus phoenicis (Acari: Tenuipalpidae). Resumos, I. Simpósio Brasileiro de Acarologia. Viçosa MG. p. 218.

Pascon RC, Kitajima JP, Breton MC, Assumpção L, Greggio C, Zanca AS, Okura VK, Alegria MC, Camargo ME, Silva GGC, Cardozo JC, Vallin M A, Franco SF, Silva VH, Jordão Junior H, Oliveira F, Giachetto PF, Ferrari F, Agioçar-Vildoso CI, Franchiscini FJB, Silva JMF, Arruda P, Ferro JA, Reinach F, Rasera da Silva AC (2006) The complete nucleotide sequence and genomic organization of citrus leprosis associated virus, cytoplasmic type (CiLV-C). Virus Genes 32:289-298.

Rodrigues JCV (2002) Programa de controle da leprose dos citros. Laranja 23:321-332.

Rodrigues JCV, Locali EC, Freitas-Astúa J, Kitajima EW (2005) Transmissibility of citrus leprosis virus by Brevipalpus phoenicis to Solanum violaefolium. Plant Disease 89:911.

Rodrigues JCV, Kitajima EW, Childers CC, Chagas CM (2003) Citrus leprosis virus vectored by Brevipalpus phoenicis (Acari: Tenuipalpidae) in citrus in Brazil. Experimental and Applied Acarology 30:161-179.

Smith AC (1991) Flora Vitiensis Nova: a new flora of Fiji. National Tropical Botanical Garden, Lawai, Kauai, Hawaii. Vol. 5.

Yamashita S, Kitajima EW (2004) Nuclear type of Brevipalpus mite-transmitted virus found in chlorotic lesions of black pepper from Para state, Brazil. Summa Phytopathologica 30(Supl):68 